\title{
Digital transformation and artificial intelligence in the activities of customs services in Russia and foreign countries
}

\author{
Anna Aleksandrovna Chebotareva $^{11}$, Natalya Gennadievna Kazantseva ${ }^{2}$, Ekaterina \\ Sergeevna Vologdina ${ }^{2}$, Tatevik Vartanovna Grigorian², and Irina Sergeevna Sukhanova ${ }^{2}$ \\ ${ }^{1}$ Russian University of Transport, Institute of Law, Department of Administrative Law, Ecological \\ Law, Information Law, Moscow, Russia \\ ${ }^{2}$ Transbaikal State University, Faculty of Law, Department of Administrative Law and Customs \\ Matter, Chita, Russia
}

\begin{abstract}
The purpose of this study is to analyze the legal framework and generalize the practical experience of world powers in the application of artificial intelligence technologies in the activities of customs services. The methodological basis of the study was made up of universal methods and special research methods, which made it possible to draw general conclusions and conduct a qualitative assessment of the relations studied in this work. The result of the research was the author's understanding of the concept of "artificial intelligence in the field of customs". The study also substantiates the conclusion about the need to improve the efficiency of customs control and accelerate customs operations with goods through the introduction of artificial intelligence into the work of customs services. Scientific novelty is characterized by the following provisions: 1) the experience of using artificial intelligence in some foreign countries, made it possible to state that there are unconditional advantages of using the artificial intelligence system in customs activities; 2) from the modern standpoint of complex branches of law, a legal conceptual apparatus has been formulated, which is used in the regulation of social relations in the course of the application of artificial intelligence technologies; 3) the generalization of the world experience of the accumulated intelligent technological solutions allows us to speak about the model of an "intelligent" checkpoint that is promising for innovative Russia.

Keywords: intellectual cooperation, robotics, Intellectual checkpoint
\end{abstract}

\section{$1 \quad$ Introduction}

The problem of legal regulation of the use of artificial intelligence in the context of the development of various information innovations is becoming increasingly relevant in foreign practice, both in general management processes and in individual industries, which creates the need for a speedy legislative response in all the advanced states of the world. The growing interest on the part of scientists in the field of artificial intelligence is largely

${ }^{1}$ Corresponding author: anna galitskaya@mail.ru 
due to its active implementation in human everyday life. Today, artificial intelligence is not at a level of development where regulation would be critically necessary, but, nevertheless, the presence of the very risk of ambiguous and controversial situations gives rise to a serious reason for anticipatory lawmaking. The problem of introducing and using artificial intelligence technologies is one of the topical topics in the research of many scientists. Such a pronounced significance of the stated topic is due to the fact that in recent years artificial intelligence in many countries is increasingly being introduced into various industries, agriculture, healthcare, finance and others. Hlavka cites the experience of introducing artificial intelligence in the United States into healthcare as a practical example and points out the problems related to privacy and data protection, noting that "education and awareness building are highly describe among the general public and healthcare workers alike, given how many social sectors data privacy and security issues permeate" [1].

Many researchers (Barchukov [2], Begishev [3], Kuzmin [4], Kuznetsov [5], Neznamov, Naumov [6], Khisamova [7], Ovchinnikov, Khakimov [8], etc.) pay attention to the issues of legal regulation and development of legislation on robotics and the use of artificial intelligence technologies. The peculiarities of the implementation and the prospects for the application of artificial intelligence technology in the activities of customs authorities are considered by domestic scientists - Markova, Martynova, Zykov [9], Polukhin [10] and others.

The authors of this study propose an innovative approach to considering the issues of legal regulation of artificial intelligence on the basis of generalized foreign experience. In this article, the features of a complex intersectoral institute of artificial intelligence in the activities of customs services, its place and role in the context of digital innovations are investigated for the first time. The authors managed to substantiate the growing role of legal regulation of the studied institute in the digital environment of customs activities in the development of the global information society and the strengthening of digitalization processes. The purpose of the study is due to the ongoing processes of digital transformation observed in various industries and spheres of human activity, and consists in justifying the need to introduce artificial intelligence technologies into the work of the Russian customs service, as well as legal regulation of their use. The implementation of the designated goal involves the solution of the following scientific tasks: to consider the practice of using artificial intelligence in the customs sphere of foreign states; to study the approaches of legal regulation of the use of artificial intelligence in the work of the customs authorities of individual countries of Europe and China; identify promising areas for the introduction of artificial intelligence technologies in the customs service of Russia.

\section{Methods}

The basis of this study was a complex of various methods. The system analysis method was used as a base one, which made it possible to comprehend and conceptualize the key sections (segments) of the studied thematic area. The use of the induction method made it possible to draw the necessary generalizing conclusions, to assess the relations studied in this work. The deduction method made it possible to qualitatively move from the generally recognized interpretations of artificial intelligence and its components to the study of features within the framework of the customs business. Special research methods - formal legal and comparative legal - allowed identifying the relevant content of the studied acts and norms of differences in the approaches implemented now within the boundaries of the integrated customs space. 


\section{$3 \quad$ Results and discussion}

To achieve the goal of this study, the authors analyzed the legal basis for the application of artificial intelligence technologies of world powers, during which it was established that the basis for the regulation of the technologies and robotics under study in the European Union is based on several documents: Roadmap for the development of robotics in Europe "Robotics 2020" [11], Declaration on Cooperation in the Field of Artificial Intelligence [12]. The results of this study allowed the authors to reveal that the modern practice of using artificial intelligence in the customs sphere of European countries is specific for the following points. Since the end of 2018, in a pilot project called "iBorderCtrl", machines with "artificial intelligence" have been introduced at border checkpoints. The work of the "iBorderCtrl" system is divided into two directions. At the initial stage, documentary control is carried out - loading a scanned image of a passport, visa. Then, while passing through passport control, the person crossing the border, using artificial intelligence, a robot, is asked questions for customs purposes using a web camera. The robot reads facial expressions, reveals involuntary facial expressions that appear when trying to hide or suppress emotions. If the artificial intelligence provides information on the existence of grounds indicating the likelihood of a person violating customs rules, then the procedure for passing biometric identification is not excluded. Consequently, the initial functions are performed by artificial intelligence, but under the supervision of a person - a customs inspector. The undoubted advantage of using artificial intelligence technology in the customs business of European countries is that, on the one hand, this technology acts as a "virtual" lie detector, and on the other, an intelligent "processor" of information about persons crossing the customs border.

Generalization of the practical experience of China in the application of artificial intelligence technologies made it possible to identify a different approach, where two levels of regulation are distinguished - national and local. In particular, the Concept of regulation of the customs sphere at the national level consists of a set of strategic documents - the Global State Development Program "Made in China-2025" [13], plans for the development of the robotic industry, as well as the Plan for the Development of New Generation Artificial Intelligence Technologies 2017 [14]. In China, there are five checkpoints using artificial intelligence, where the time for the release of risk-free goods has been significantly reduced, which indicates the favorable conditions for the movement of goods across the customs border. In addition, well-known Chinese integrators such as Huawei and Nuctech are working to develop an "intelligent customs infrastructure". China's customs also use an innovative model of an intelligent checkpoint: at the border with the Hong Kong Special Administrative Region, there is a "smart" automobile customs post "Huanggang" of the Shenzhen Customs, in the ports of Guangdong province robots are used as "customs officials".

Due to the global automation of customs operations performed using artificial intelligence technologies, favorable conditions for the movement of goods and vehicles across state (customs) borders have been identified. So, in the Netherlands, in the port of Rotterdam at checkpoints, almost a full range of cargo operations is provided by robots, while the role of a customs inspector is performed by 2-3 people. In Japan, an automated information system for interdepartmental interaction is actively used, which is integrated with the information subsystems of absolutely all government agencies.

Based on the foregoing, we believe that in world practice, a sufficient number of intelligent technological solutions have been developed that would be advisable for Russia to take into account. The Institute of Artificial Intelligence in the Russian legal system is relatively new, as a result of which the emergence of the "intellectual customs" paradigm of the customs service is due to the strategic goal of developing the system of customs 
authorities of the Russian Federation, which is formulated in "Strategy-2030" [15]. Development and implementation of a new model of an "intelligent" checkpoint in the work of the customs authorities of Russia is considered promising in the area under study. It is assumed that its functioning will be based on a unified information system, the technical properties of which will ensure operation according to the principle of a "single point of receipt" of preliminary information for various controlling entities at the checkpoint. In this regard, it seems important to establish the processes of integration and convergence of a single information system of an intelligent checkpoint with software for technical means of customs control. Despite the positive trends caused by the introduction of artificial intelligence at the initial stage, insufficient equipment of checkpoints remains an acute problem in the development of customs technologies on the border of the Russian Federation. According to statistics, about $15 \%$ of checkpoints comply with the Unified Standard Requirements for Equipment and Material and Technical Equipment of Buildings, Premises and Structures [16], about two thirds of checkpoints need significant technological reconstruction and modernization. Therefore, innovative material and technical support of checkpoints, in accordance with the new customs concept, is considered important in the area under study. The action plan of the Federal Customs Service of Russia until 2024 for the implementation of the 2030 Strategy determines that the construction and modernization of checkpoints should take into account the infrastructure that has been created in the border regions of the Russian Federation, but taking into account the new technology of "artificial intelligence". The expected effect will lead to the creation of the most favorable conditions for the non-stop movement of goods and vehicles across the customs border and will allow participants in foreign economic activity to submit information for customs control once, due to the global and full automation of customs operations performed using modern information technologies, using artificial intelligence. As a result, the customs sphere will become more transparent, based on informational trust between customs authorities and business.

\section{Conclusion}

The analysis of the practice of using artificial intelligence in some foreign countries allows us to conclude that there are a number of unconditional advantages in using the artificial intelligence system in customs activities, a specific approach to regulating legal regulation issues. Practical experience in the implementation of intelligent technologies in customs, allows us to give the following definition of the studied phenomenon: "artificial intelligence in the field of customs" is a program that implements specified algorithms for processing large arrays of customs information and data in a short time, allowing through mathematical methods (extrapolation, interpolation, calculus of variations) predict, evaluate individual processes and prepare (or make automatically) decisions. Analysis of the legislator's position, generalization of the experience of foreign countries in this matter would significantly increase the level of business confidence in customs activities. The position that "artificial intelligence, like other technical electronic means, remains a human assistant, but does not replace it in full, epistemological, psychological and other features peculiar only to a person" [17], seems to be fair. The knowledge, abilities, skills and competence of the customs authorities should be organically integrated into the work of artificial intelligence, but it should be borne in mind that, regardless of the degree of perfection of information products, the role of a person remains the leading one.

\section{References}


1. J.P. Hlavka, Security, privacy, and information-sharing aspects of healthcare artificial intelligence, in Artificial Intelligence in Healthcare (Elsevier, 2020)

2. V.K. Barchukov, Euras. Law J. 7(146), 275-278 (2020)

3. I.R. Begishev, Int. Pub. and Priv. Law 1, 37-40 (2021). https://doi.org/10.18572/1812-3910-2021-1-37-40

4. D.V. Kuzmin, Modern Sci.: Top. Prob. Theory and Pract. Ser.: Econ. and Law 10, 163-171 (2020). https://doi.org/10.37882/2223-2974.2020.10.17

5. A.K. Kuznetsov, Modern Sci.: Top. Prob. Theory and Pract. Ser.: Econ. and Law 10, 544-549 (2020). https://doi.org/10.37882/2223-2974.2020.10.15

6. A.V. Neznamov, V.B. Naumov, Leg. Res. 8, 16 (2017)

7. Z.I. Khisamova, I.R. Begishev, Baikal Res. J. 10(2), 19 (2019)

8. A.I. Ovchinnikov, I.A. Khakimov, Leg. Techn. 14, 481-484 (2020)

9. A.M. Markova, E.S. Martynova, A.A. Zykov, Perspektivy primeneniya iskusstvennogo intellekta $v$ tamozhennykh organakh Rossiiskoi Federatsii [Prospects for the use of artificial intelligence in the customs authorities of the Russian Federation], in Actual problems of customs in the context of the functioning of the Eurasian Economic Union: Proc. of the XI Int. Sci. and Pract. Conf.. State treasury educational institution of higher education, 130-133 (Russian Customs Academy, 2020)

10. I.V. Polukhin, Log. Sys. Glob. Econ. 10, 238-240 (2020)

11. Robotics 2020 Multi-Annual Roadmap: For Robotics in Europe. Horizon 2020 Call ICT-2016 (ICT-25 \& ICT-26). Accessed on: July 11, 2021. [Online]. Available: https://www.eu-robotics.net/sparc/upload/about/files/H2020-Robotics-Multi-Annual-R oadmap-ICT-2016.pdf

12. EU Member States sign up to cooperate on Artificial Intelligence. Accessed on: July 11, 2021. [Online]. Available:

https://ec.europa.eu/digital-single-market/en/news/eu-member-states-sign-cooperate-art ificial-intelligence

13. Made in China 2025: Global Ambitions Built On Local Protections. Accessed on: July 11, 2021. [Online]. Available:

https://www.uschamber.com/report/made-china-2025-global-ambitions-built-local-prot ections- 0

14. 国务院关于印发 新一代人工智能发展规划的通知 国发 2017 [The plan for the development of artificial intelligence technologies of a new generation 2017].

Accessed on: July 11, 2021. [Online]. Available:

http://www.gov.cn/zhengce/content/2017-07/20/content_5211996.htm

15. Ob utverzhdenii Strategii razvitiya tamozhennoi sluzhby Rossiiskoi Federatsii do 2030 goda: rasporyazhenie Pravitelstva Ros. Federatsii (ot 23 maya 2020 g. № 1388-r) [On the approval of the Development Strategy of the Customs Service of the Russian Federation until 2030: order of the Government of the Russian Federation. Federation (dated May 23, 2020 No. 1388-r)], in Coll. of legislation of Russian Federation, 22, $3572(2020)$

16. Reshenie Komissii Tamozhennogo soyuza ot 22 iyunya 2011g. № 688 “O Edinykh tipovykh trebovaniyakh k oborudovaniyu i materialno-tekhnicheskomu osnashcheniyu zdanii, pomeshchenii i sooruzhenii, neobkhodimykh dlya organizatsii pogranichnogo, tamozhennogo, sanitarno-karantinnogo, veterinarnogo, karantinnogo fitosanitarnogo i transportnogo kontrolya, osushchestvlyaemykh v punktakh propuska cherez vneshnyuyu granitsu gosudarstv - chlenov Tamozhennogo soyuza, Klassifikatsii 
punktov propuska cherez vneshnyuyu granitsu gosudarstv - chlenov Tamozhennogo soyuza i forme Pasporta punkta propuska cherez vneshnyuyu granitsu gosudarstv chlenov Tamozhennogo soyuza" [Decision of the Customs Union Commission No. 688 of June 22, 2011 "On Uniform Standard requirements for equipment and material and Technical equipment of buildings, Premises and Structures necessary for the organization of border, Customs, Sanitary-quarantine, Veterinary Quarantine Phytosanitary and Transport Control carried out at Checkpoints across the External Border of the Customs Union Member States, Classification of Checkpoints across the External Border of the Customs Union Member States and the Passport form of the Checkpoint across the external border of the Customs Union Member States"]. Accessed on: July 11, 2021. [Online]. Available: https://www.alta.ru/tamdoc/11sr0688

17. N.A. Dukhno, Yurisprudentsiya $i$ iskusstvennyi intellekt [Jurisprudence and artificial intelligence], in A.A. Chebotareva, V.E. Chebotarev (eds.), Materials of the Second International Transport and Legal Forum (Publishing house of the MIIT Law Institute, Moscow, 2020) 